\title{
EFFECT OF THE GROWTH REGULATORS ON THE DEVELOPMENT OF SELECTED CONIFER TREES
}

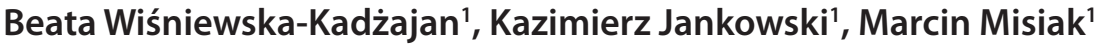 \\ 1 Department of Grassland and Green Areas Creation. Siedlce University of Natural Sciences and Humanities, \\ 08-110 Siedlce, Poland, e-mail: beata.wisniewska-kadzajan@uph.edu.pl
}

Received: 2016.12 .19

Accepted: 2017.01.16

Published: 2017.03.01

\begin{abstract}
Nowadays, substances stimulating the growth and development of different agricultural plant species are used in intensive farming. Some of such plant growth regulators are Asahi SL and Moddus 250-EC. So far the literature dealing with growth regulators has focused mainly on their effects on deciduous trees. Because no data are available on how those substances affect conifer trees, this paper presents description of experiments on the effects of Asahi SL and Moddus 250-EC on the increase of tree height and branch length of Picea pungens and Thuja occidentalis. The research has proved that morphological features of the plants tested in the experiment varied according to which growth regulator was used and in what month the measurements were taken. Conifer trees sprayed with Asahi SL had a bigger yearly height growth rate and bigger growth of branches than those sprayed with the stimulator Moddus 250-EC.
\end{abstract}

Keywords: bio-regulator, active substance, Picea pungens, Thuja occidentalis, plant growth.

\section{INTRODUCTION}

Prevention of stress is one of the objectives of arable farming. To this end, farmers take more and more interest in using different methods to improve growing conditions of crop plants, in particular in a stressful environment. Biologically active substances containing hormones, enzymes, protein, amino acids, microelements and other chemical compounds are called bio-stimulators. Used mostly in small doses, they speed up metabolism, which results in a quicker growth and development of plants [Jankowski and Dubis 2008].

The application of bio-stimulators in crop production is a method of making plants benefit better from their growing conditions, i.e. soil quality, absorption of mineral nutrients, temperature, air humidity and amount and intensity of light [Bebhardt 2002; Matysiak and Adamczewski 2009].

Bio-stimulators affect metabolism in a plant cell, but they also have a positive impact on plant organs and a plant as a whole. Przybysz et al. [2010] underlines the fact that the first bio-stim- ulator widely used in horticulture was Asahi SL, a unique product based on three active substances of the nitro phenols group, which all take part in plant metabolism in natural conditions. The effect of using Asahi SL is a higher yield and a higher quality of crops in agriculture, horticulture and in growing vegetables both in fields and greenhouses [Czyż and Harasimowicz-Hermann 2008; Harasimowicz-Hermann and Czyż 2008; Bąbelewski 2008; Bąbelewski and Dębicz 2006; Kołodziej 2008].

Another bio-stimulator is Moddus 250-EC, whose effects were tested on lawn grassand other plants [Jankowski et al.; 2012 2014, Czeluściński et al. 2008] as well as on cereals grown with the use of intensive crop cultivation and a high dose of nitrogen fertilizers [Hafner 2001; Wróbel and Woźniak 2008 a,b].

As said above, in literature the effect of growth regulators on trees is not sufficiently presented and is limited to deciduous trees, with only a few publications on ornamental trees [Adamiak and Hetman 2007; Bąbelewski and Dębicz 2006; 
Hetman and Adamiak 2003], and with no publications about testing the effects of bio-stimulators on conifer trees.

The aim of this paper is to compare the effects of Asahi SL and Moddus 250-EC on some morphological features of Picea pungens and Thuja occidentalis.

\section{MATERIAL AND METHODS}

The experiment was carried out in a nursery of ornamental trees and bushes in Ceranów $\left(52.63^{\circ} \mathrm{N} ; 22.23^{\circ} \mathrm{E}\right)$, located in the Masovian Voivodship, in the county of Sokołów (Figure 1). Fifteen trees were marked and selected out of three-year-old seedlings of the blue spruce ( $P i$ cea pungens Engelm.) the variety of Glauca and the northern white-cedar (Thuja occidentalis) of the Smaragd variety. The plot with the trees was weeded and taken care of in the first year of the field experiment. The trees grew in soft and loose soil of class 5, according to the Polish classification system. In April 2013 the applied substances were the following regulators: Asahi SL and Moddus 250-EC in a dose of $100 \mathrm{ml}$ in 1001 of water.
In the experiment there were three test plots: $\mathrm{O}-\mathrm{a}$ control plot where no regulators were used, A - where the trees were sprayed with Ashai SL, $\mathrm{M}$ - where the trees were sprayed with Moddusem 250-EC. The morphological features tested in the experiment were the increase of the trees in height and the growth of branches in length.

Measurements of the increase were made each time on marked parts of plants and were carried out on the 27th of each month from the beginning of May till the end of September. Meteorological data for the area where the experiment was carried out were provided by the Meteorological and Hydrological Station in Siedlce. Selyaninov's hydrothermal coefficient was used to determine variability of meteorological conditions in time and their effect on plant growth.

The data presented in Table 1 indicate that the best weather conditions during the growing period were in May and September, with the most beneficial temperature and distribution of rainfall. For those months the hydrothermal coefficient was the highest, which means that the ratio of the air temperature to rainfall was optimal $(K>2)$. It is worth mentioning that in August there was water deficiency, resulting in a drought $(\mathrm{K}=0.25)$.

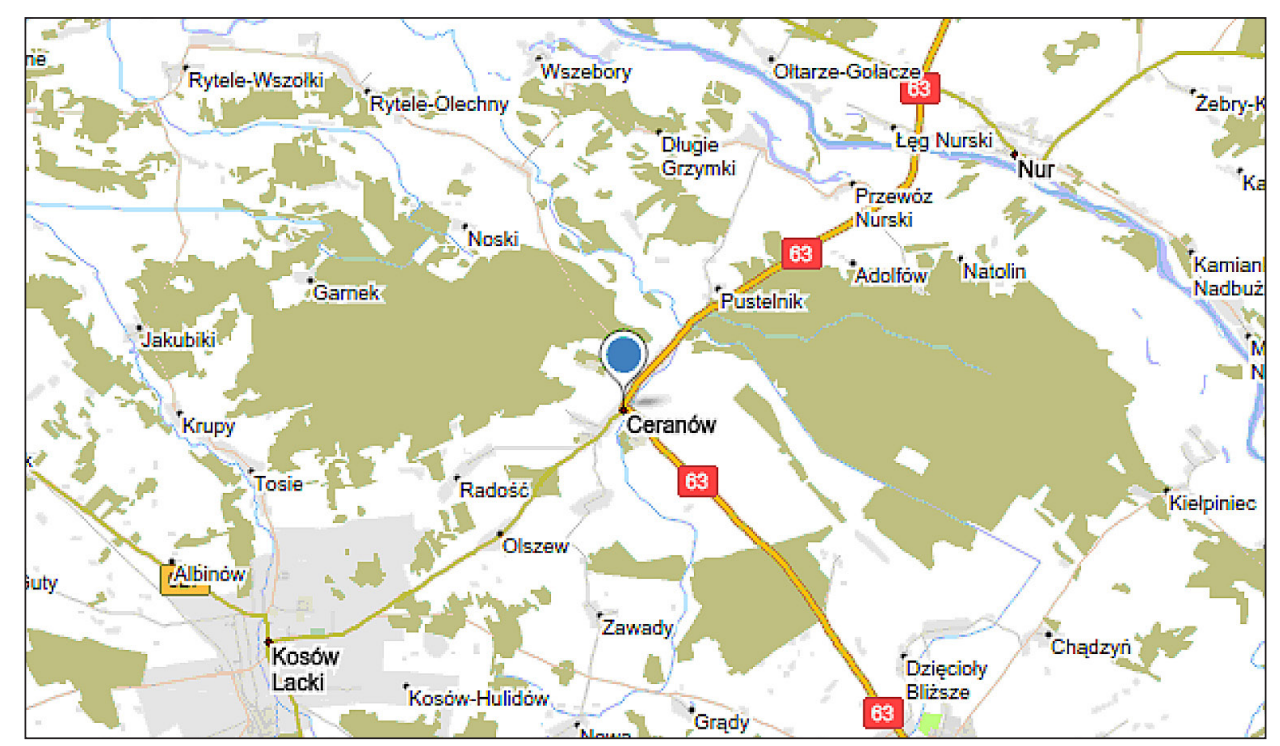

Figure 1. Schematic location of the place of experiment

Table 1. Hydrotermical Sielianinow index $(\mathrm{K})$ in individual months of vegetation seasons

\begin{tabular}{|c|c|c|c|c|c|c|c|}
\hline \multirow{2}{*}{ Year } & \multicolumn{7}{|c|}{ Month } \\
\cline { 2 - 9 } & IV & V & VI & VII & VIII & IX & X \\
\hline 2013 & 1.60 & 2.20 & 1.80 & 1.50 & 0.25 & 2.70 & 1.22 \\
\hline
\end{tabular}

$\mathrm{K}<0.5$ high drought; $0.51-0.69$ drought; $0.70-0.99$ - poor drought; $\mathrm{K}>1$ no drought. 
The growth rate indicators of the height of ornamental trees and the length of their organs were worked out using the measurements made before and after the regulators were applied.

$$
\mathrm{W}_{\mathrm{p}}=\frac{\mathrm{A}}{\mathrm{B}}
$$

where: $W_{p}=$ growth rate indicator;

$A$ - the height (length) of the tree (or its organ) when it was measured the first time

$B$ - the height (length) of the tree (or its organ) when it was measured the last time

The data obtained during the experiment were analyzed statistically using the program Statistica, Version 10.0 StatSoft, whereas to verify means Tukey's test was used with the significance level $\mathrm{p} \leq 0.05$. The linear regression equation was also worked out $(\mathrm{Y}=\mathrm{a}+\mathrm{bx})$ together with the value of the correlation coefficient $(n=39)$ to know the relation between the tested features.

\section{RESULTS AND DISCUSSION}

The increase in the tree height (Table 2) was varied and was in relation to the regulator used and to the month in which the measurement was taken. The highest growth of Picea pungens with both bio-stimulators used was in June $(\mathrm{M}-15 \mathrm{~cm}$ and $\mathrm{A}-23 \mathrm{~cm})$. In May the growth was smaller but compared to the control plot it was more varied $(\mathrm{M}-13.20$ and $\mathrm{A}-9.30 \mathrm{~cm})$. In the case of Thuja occidentalis with both bio-stimulators used, the biggest growth was in June ( $\mathrm{M}-11.20$ and A $15.40 \mathrm{~cm})$ and July $(\mathrm{M}-14.70$ and $\mathrm{A}-15.30 \mathrm{~cm})$.

The variability in time intervals of the growth rate of the trees tested during the first three months of the experiment may have been caused by different speed of the regulators activity and the physiology of the trees. Compared to the height increase in the control plot the height increase of Thuja occidentalis with growth regulators was fast in August $(\mathrm{O}-1.50, \mathrm{M}-5.40$ and $\mathrm{A}-6.60$ $\mathrm{cm})$. The measurements taken showed a positive effect of growth regulators on the trees tested in particular in that month, despite the fact that in August Selyaninov's hydrothermal coefficient indicated a drought. The results also showed that bio-stimulators made the plant more tolerant to unfavorable stress factors, such as water shortage, which slow down its growth and development.

The biggest height increase (Figure 2) of Picea pungens and Thuja occidentalis was seen when Asahi SL was used (36.50 and $42.70 \mathrm{~cm}$ respectively for both species) while for Moddus 250-EC the height increase was smaller (31.8 and $38.9 \mathrm{~cm}$ respectively). In both cases growth regulators considerably increased the height of trees in the tested plots compared to the trees in the control plot.

The use of the bio-stimulator Moddus 250EC made conifer trees increase their height one and a half times while the bio-stimulator Asahi SL made the trees increase their height two times compared to the control plot where no growth regulator was used. The increase in the length of the branches of the trees (Table 3) was significantly varied and was dependent on the type of bio-stimulator used and the month when the measurement was taken.

The biggest branch growth of Picea pungens sprayed with bio-stimulators, compared to the control plot, was seen in the first two month of taking the measurements, in May $(\mathrm{M}-1.20$, $\mathrm{A}-1.20$ $\mathrm{cm})$ and in June $(\mathrm{M}-2.80, \mathrm{~A}-3.30 \mathrm{~cm})$. In the next months the growth in length was not so great.

Table 2. Increments height $(\mathrm{cm})$ of the tested trees under the influence of the applied growth regulators

\begin{tabular}{|c|c|c|c|c|c|c|c|}
\hline \multirow{2}{*}{ Species } & \multirow{2}{*}{ Regulator } & \multicolumn{5}{|c|}{ The term of measurement (month) } & \multirow{2}{*}{ Mean } \\
\hline & & V & VI & VII & VIII & IX & \\
\hline \multirow{4}{*}{$\begin{array}{c}\text { Picea } \\
\text { pungens }\end{array}$} & $\mathrm{O}$ & 4.50 & 10.50 & 1.30 & 1.50 & 0.40 & 3.64 \\
\hline & M & 13.20 & 15.00 & 1.50 & 1.30 & 0.80 & 6.36 \\
\hline & $A$ & 9.30 & 23.00 & 1.30 & 2.40 & 0.50 & 7.30 \\
\hline & Mean & 9.00 & 16.16 & 1.37 & 1.73 & 0.56 & \\
\hline \multirow{4}{*}{$\begin{array}{c}\text { Thuja } \\
\text { occidentalis }\end{array}$} & $\mathrm{O}$ & 2.40 & 10.30 & 10.30 & 1.50 & 0.30 & 4.96 \\
\hline & $M$ & 6.30 & 11.20 & 14.70 & 5.40 & 1.30 & 7.78 \\
\hline & $A$ & 4.30 & 15.40 & 15.30 & 6.60 & 1.10 & 8.54 \\
\hline & Mean & 4.33 & 12.3 & 13.43 & 4.50 & 0.90 & \\
\hline \multirow{2}{*}{\multicolumn{2}{|c|}{$\begin{array}{l}\mathrm{A}=\text { kind of regulator } \\
\mathrm{B}=\text { plant species } \\
\mathrm{C}=\text { term of measurement }\end{array}$}} & $A=2.58$ & \multicolumn{2}{|c|}{$\mathrm{B}=\mathrm{n} . \mathrm{s}}$. & \multicolumn{2}{|c|}{$\mathrm{C}=4.03$} & \\
\hline & & $\begin{array}{l}\mathrm{A} / \mathrm{B}=\text { n.s. }-\mathrm{n} . \mathrm{i} . \\
\mathrm{C} / \mathrm{A}=\text { n.s. }-\mathrm{n} . \mathrm{i} .\end{array}$ & \multicolumn{2}{|c|}{$\begin{array}{c}\mathrm{B} / \mathrm{A}=\text { n.s. }- \text { n.i. } \\
\mathrm{B} / \mathrm{C}=3.80\end{array}$} & \multicolumn{2}{|c|}{$\begin{array}{c}\mathrm{A} / \mathrm{C}=\text { n.s. }- \text { n.i. } \\
\mathrm{C} / \mathrm{B}=5.69\end{array}$} & \\
\hline
\end{tabular}




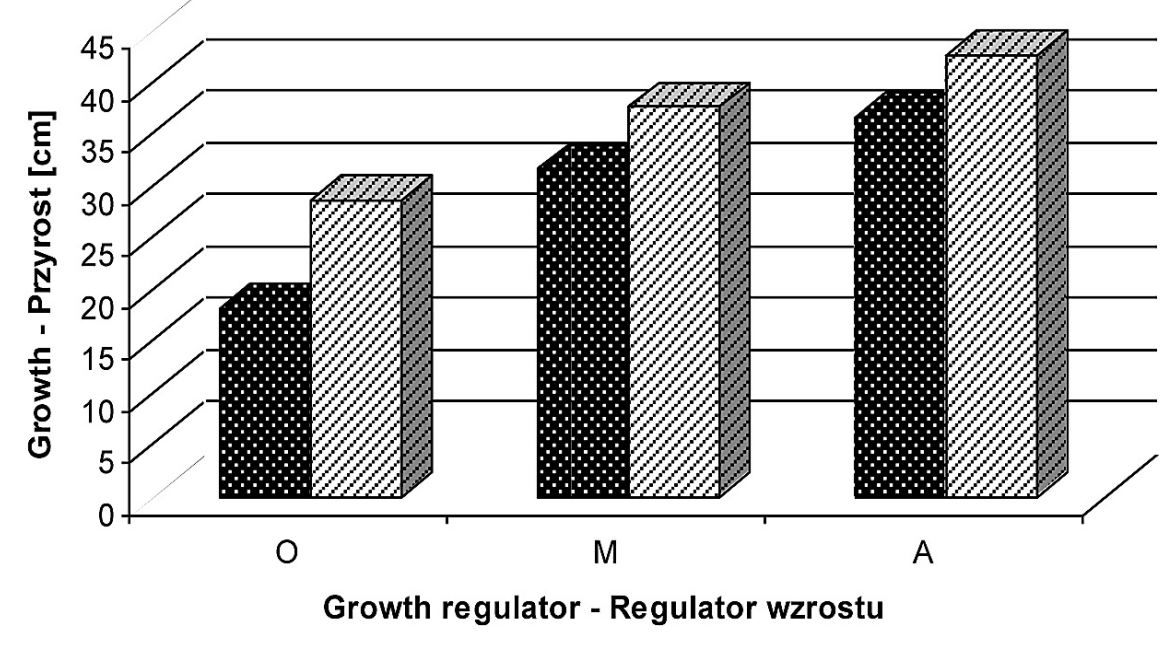

- Picea Pungens $\square$ Thuja occidentalis

Figure 2. Annual (summary) increases of high the tested trees depending on the applied growth regulators

Table 3. Increase in the length of branch $(\mathrm{cm})$ of the tested trees depending on the applied growth regulators

\begin{tabular}{|c|c|c|c|c|c|c|c|}
\hline \multirow{2}{*}{ Species } & \multirow{2}{*}{ Regulator } & \multicolumn{5}{|c|}{ The term of measurement (month) } & \multirow{2}{*}{ Mean } \\
\hline & & V & VI & VII & VIII & IX & \\
\hline \multirow{4}{*}{$\begin{array}{c}\text { Picea } \\
\text { pungens }\end{array}$} & 0 & 0.20 & 0.50 & 0.10 & 0.10 & 0.10 & 0.20 \\
\hline & M & 1.20 & 2.80 & 0.10 & 0.50 & 0.10 & 0.94 \\
\hline & A & 1.20 & 3.30 & 0.50 & 1.20 & 0.10 & 1.26 \\
\hline & Mean & 0.86 & 2.20 & 0.23 & 0.60 & 0.10 & \\
\hline \multirow{4}{*}{ Thuja occidentalis } & $\mathrm{O}$ & 0.20 & 1.00 & 0.10 & 0.90 & 0.10 & 0.44 \\
\hline & $\mathrm{M}$ & 0.90 & 1.60 & 0.90 & 1.00 & 0.10 & 0.90 \\
\hline & A & 1.60 & 4.00 & 1.40 & 1.50 & 0.10 & 1.72 \\
\hline & Mean & 0.90 & 2.20 & 0.80 & 1.23 & 0.10 & \\
\hline $\mathrm{A}=$ kind regulator & \multicolumn{2}{|c|}{$A=0.49$} & \multicolumn{2}{|c|}{$\mathrm{B}=\mathrm{n} . \mathrm{s}$} & \multicolumn{2}{|c|}{$\mathrm{C}=0.77$} & \\
\hline $\mathrm{B}=$ plant species & \multirow{2}{*}{\multicolumn{2}{|c|}{$\begin{array}{c}\mathrm{A} / \mathrm{B}=\text { n.s. }- \text { n.i. } \\
\mathrm{C} / \mathrm{A}=1.30\end{array}$}} & \multirow{2}{*}{\multicolumn{2}{|c|}{$\begin{array}{c}\mathrm{B} / \mathrm{A}=\text { n.s. }- \text { n.i. } \\
\mathrm{B} / \mathrm{C}=\text { n.s. }\end{array}$}} & $=1.11$ & & \\
\hline $\mathrm{C}=$ term of measu & & & & & $=$ n.s. & & \\
\hline
\end{tabular}

Compared to the control plot, the biggest branch length increase of Thuja occidentalis sprayed with the regulators was seen in May $(\mathrm{M}$ $-0.90, \mathrm{~A}-1.60 \mathrm{~cm})$, July $(\mathrm{M}-1.60, \mathrm{~A}-4 \mathrm{~cm})$ and August $(\mathrm{M}-0.90, \mathrm{~A}-1.40 \mathrm{~cm})$. In the last month of taking the measurements both for Picea pungensand and Thuja occidentalis there was no significant growth of the branches in all plots.

The results of the measurements of the branch growth of Picea pungens observed in August, when the weather was dry, and in the same month the results of the height growth of Thuja occidentalis showed similar response patterns of the trees. In that month, compared to the control plot, the branch growth of tress in plots sprayed with regulators was 5 to 12 times bigger. It clearly indicates that the stimulators made up for the drought. In total, the biggest annual branch growth of both tested trees (Figure 3) was observed for the Asahi SL regulator, with $6.30 \mathrm{~cm}$ for Picea pungens and $8.60 \mathrm{~cm}$ for Thuja occidentalis.

Compared to the trees where no regulator was used, annual branch growth of Picea pungens was five times higher for the regulator Moddus 250-EC and six times for the Asahi SL regulator. It also turned out that the growth regulators affected Thuja occidentalis less because the branch growth of that tree was smaller than in the case of Picea pungens.

In relation to the trees in the control plot, the branch growth of Thuja occidentalis sprayed with Moddus 250-EC was two times bigger, while sprayed with Asahi SL four times bigger. Statistical analysis showed a significant correlation between the increase in the height of the trees and the increase in the length of the branches of the 


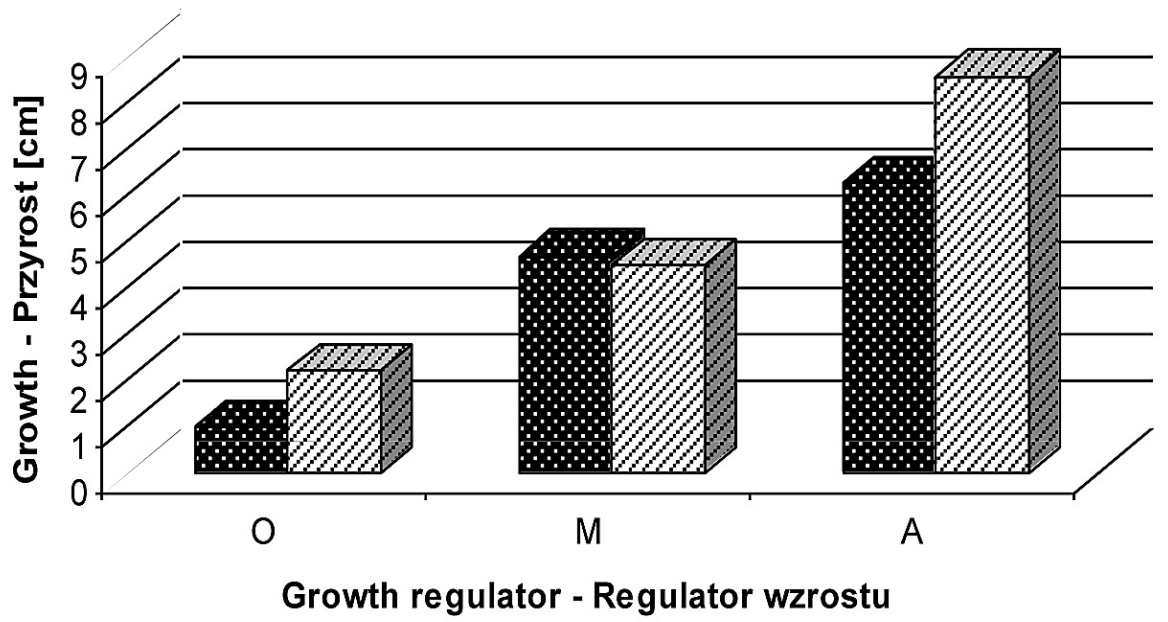

Dicea Pungens 0 Thuja occidentalis

Figure 3. Annual (summary) increases the length of branches of tested trees depending on the applied growth regulators

ornamental trees sprayed with the growth regulators (Figure 4). The value of the correlation coefficient (r) was 0.77 (for $\mathrm{n}=39$ ) and the linear regression equation was $\mathrm{Y}=0.13+0.12 \mathrm{x}$.

For both Moddus 250-EC and Asahi SL growth rates of the height of the trees and of the length of branches were worked out. To do that, tree height and branch length measurements of the trees stimulated with Moddus 250-EC and Asahi SL were taken at the beginning of the growing season, before the regulators were used, and at the end of the growing season.

The biggest growth rate (Table 4) of the height of Picea pungens and Thuja occidentalis (1.80 and 2.06 respectively) as well as the growth rate of their branches (3.10 and 4.44 respectively) were on the plots where Asahi SL was used.
The height growth rates of Picea pungens and Thuja occidentalis in the plots where the Moddus 250-EC bio-stimulator was used were 1.62 and 2.02 respectively, with the growth rates of branches 2.34 and 2.66. In similar experiments carried out by Jankowski et al. [2014], where the influence of the Moddus 250-EC and Asahi SL bio-stimulators on the changes of morphological features of the yellow pine was tested, the Moddus 250-EC stimulator had more significant effects.

The studies carried out by Hetman and Adamiak [2003, 2005], in which plants used for grafting stocks were treated with Asahi SL, proved that the regulator positively affected the quality of both stocks and scions of the rosa polyantha (Rosa multiflora), increasing the diameter and length of collar roots, the mass of roots, shoots and tillers of the plant, compared to bushes in the control plot.

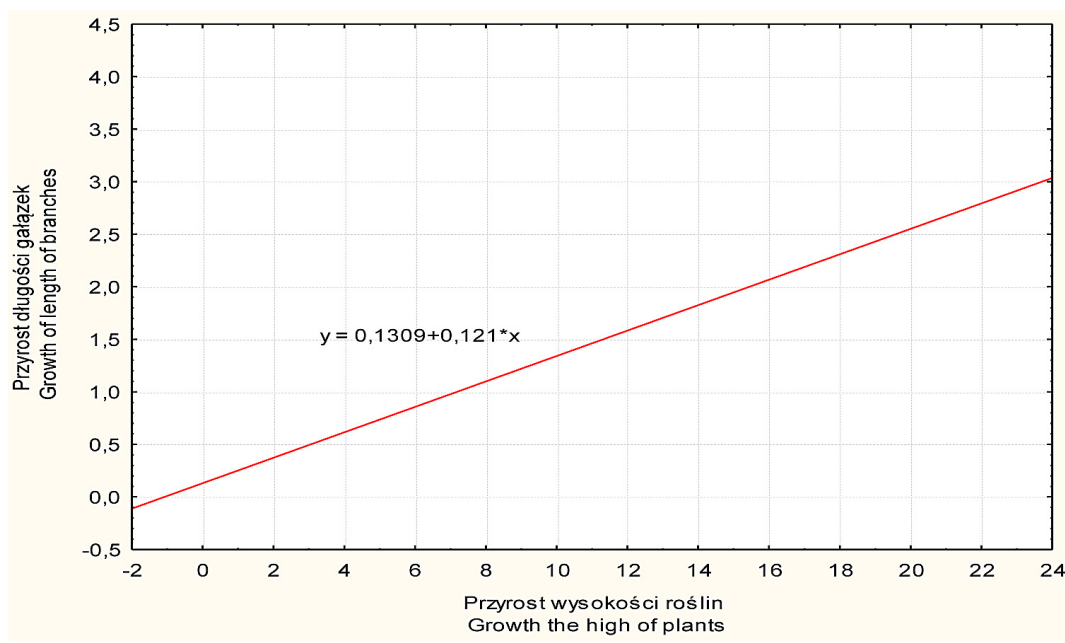

Figure 4. Correlation between the increase the morphological parts studied trees treated with growth regulators 
Table 4. Indicators growth in plant height and length of the branches of the trees tested according growth regulator

\begin{tabular}{|c|c|c|c|}
\hline \multirow{2}{*}{ Species } & \multirow{2}{*}{ Regulator } & High of plants & \multicolumn{2}{|c|}{ Indicators growth } \\
\cline { 2 - 4 } & & 1.38 & 1.31 \\
\hline \multirow{3}{*}{ Picea pungens } & $\mathrm{O}$ & 1.62 & 2.34 \\
\cline { 2 - 4 } & $\mathrm{M}$ & 1.80 & 3.10 \\
\cline { 2 - 4 } $\begin{array}{c}\text { Thuja } \\
\text { occidentalis }\end{array}$ & $\mathrm{A}$ & 1.70 & 1.85 \\
\cline { 2 - 4 } & $\mathrm{O}$ & 2.02 & 2.66 \\
\cline { 2 - 4 } & $\mathrm{M}$ & 2.06 & 4.44 \\
\hline
\end{tabular}

In a field experiment done by Bąbelewski [2008] the results of the measurements of the length of the root system, the height of the plants and the number of main and secondary roots of Thuja occidentalis of Rheingold and Sunkist varieties showed a beneficial effect of Asahi SL on the morphological features tested.

Czyż and Harasimowicz-Hermann [2008] carried out an experiment with the Asahi SL regulator used to stimulate putting down roots of woody seedlings of the willow. They proved that it quickened the growth of a bigger amount of root mass than in plants not treated with the bio-stimulator. In particular, it also happened when there was a shortage of water in the soil. Moreover, a study done by Wróbel and Woźniak [2008 a, b] showed a beneficial effect of the Antonik (Asahi $\mathrm{SL}$ ) regulator on the common osier willow (Salix viminalis), when the number of shoots was bigger and the biomass yield higher. Besides, photosynthesis and transpiration processes were more intensive and there was an increase in the concentration of macro and microelements. A study done by Przybysz et al. [2010], whose aim was the assessment of beneficial influence of Asahi SL on Arabidopsis thaliana and Amaranthus hybri$d u s$, proved that the use of the stimulator made the biomass yield higher because of bigger areas of leaves and a bigger content of chlorophyll and a higher intensity of photosynthesis.

To sum up, it is obvious that the application of the bio-stimulators Moddus 250-EC and Asahi SL on conifer trees of the Picea pungens and Thuja occidentalis species beneficially affected morphological features tested in the experiment when compared to the control plot where the regulators were not used. Measurements of the height of trees and length of branches showed that the effects of Asahi SL was higher than Moddus 250-EC.

\section{CONCLUSIONS}

1. The increase in the height of the conifer trees tested and the increase in the length of branches significantly varied according to the type of the regulator applied and was dependent on the month in which the measurement was taken.

2. The bio-stimulator Asahi SL caused a bigger annual tree growth in height and branch growth in length than the bio-stimulator Moddus 250-EC.

3. The growth regulators used stimulated a big increase in the height of Thuja occidentalis and a big branch growth of Picea pungens in the month when the value of Sielianinov's hydrothermal coefficient indicated a drought., which proves the beneficial effect of the regulators on the growth and development of plants in stressful conditions.

\section{REFERENCES}

1. Adamiak J., Hetman J. 2007. Wpływ następczy preparatów Asahi SL i tytanitu stosowanego w uprawie Rosa multiflora Thunb. na jakość okulantów róż odmiany Flamingo. Rocz. AR Poznań. CCCLXXXIII, Ogrodn. 41, 5-10.

2. Bąbelewski P. 2008. wpływ preparatu Asahi SL na jakość ukorzenionych sadzonek wybranych krzewów ozdobnych z rodzaju żywotnik (Thuja sp.). Zesz. Probl. Post. Nauk Roln. 525, 33-38.

3. Bąbelewski P., Dębicz R. 2006. Wpływ preparatu Asahi SL na wzrost i jakość rozsady torenii ogrodowej (Torenia Fournieri Linden) i fuksji mieszańcowej (Fuchsia Hybryda). Zesz. Nauk UP Wrocław, Rolnictwo LXXXIX 546, 37-41.

4. Bebhardt R., Broschewitz B., Goltermann S., Michel V. 2002. Eisatz von Wachstumsreglern im Getreide. Getreide Magazin. 1, 26-29.

5. Czeluściński W., Jankowska J., Ciepiela G. 
A., Jankowski K. 2008. Wpływ regulatora wzrostu Moddus $250 \mathrm{EC}$ na tempo odrostu muraw trawnikowych, w zależności od rodzaju zastosowanych nawozów, Biostymulatory w nowoczesnej uprawie roślin. Wieś Jutra, 68.

6. Czyż K., Harasimowicz-Hermann G. 2008. Wpływ wybranych regulatorów wzrostu na poczatkowy rozwój sadzonek wierzby (Salix) w zależności od wilgotności gleby. Fragmenta Agronomica XXV, 2 (98) 26-36.

7. Hafner V. 2001. Moddus - univerzalni pripravek za preprecevanje poleganja zit. Zbornik 5-Slovensko-Posvetovanje o Varstvu Rastlin. Ljubljana, 6-8 marec 2001, 167-172.

8. Harasimowicz-Hermann G., Czyż K. 2008. Effect of Asahi SL on the initial development of willow cuttings at varied soil moisture. Rozdz. w monografii Biostimulators in modern agriculture - ornamental and special plants. Wieś Jutra, Warszawa. 40-45.

9. Hetman J., Adamiak J. 2003. Wpływ Ashai SL na jakość podkładki róży wielokwiatowej (Rosa multiflora Thunb.). Zesz. Prob. Post. Nauk. Roln. 491, 61-65.

10. Hetman J., Adamiak J. 2005. Wpływ przemiennego dolistnego stosowania Asahi SL i tytanitu na jakość róży wielokwiatowej (Rosa multiflora Thunb.). Zesz. Probl. Post. Nauk. Roln. 504, 399-406.

11. Jankowski K., Czeluściński W., Jankowska J., Kolczarek R., Sosnowski J. 2012. The influence of the growth regulator trinexapac-ethyl on the regrowth rate of lawn grasess. Acta Sci. Pol. Hortorum Cultus, 11(4), 67-76.

12. Jankowski K., Dubis B. 2008. Biostymulatory w polowej produkcji roślinnej, Biostymulatory w nowoczesnej uprawie roślin. Wieś Jutra, 24.

13. Jankowski K., Sosnowski J., Wilk A., Malinowska E., Wiśniewska-Kadżajan B. 2014. Effect of growth regulators on selected morphological features of Yellow pine. Journal of Ecological Engineering, 15(4), 105-108.

14. Kołodziej B. 2008. The effect of plantation establishment metod and Antonik application in goldenrod (Solidago virguarea L. ssp. virguarea) cultivation. Acta Sci. Pol. Hortorum cultus, 7(3), 33-39.

15. Matysiak K., Adamczewski K. 2009. Regulatory wzrostu i rozwoju roślin - kierunki badań w Polsce i na świecie. Postępy w Ochronie Środowiska, 49(4), 1810-1816.

16. Przybysz A., Wrochna M., Słowiński A., Gawrońska H. 2010. Stimulatory effect of Asahi SL on selected plant species. Acta Sci. Pol. Hortorum Cultus, 9(2) 53-64.

17. PrzybyszA., WrochnaM., Słowiński A., Gawrońska H. 2010. Stimulatory effect of Asahi SL on selected plant species. Acta Sci. Pol. Hortorum Cultus, 9(2), 53-64.

18. Wróbel J., Woźniak A. 2008a. Wpływ sposobów stosowania stymulatora wzrostu Atonik na aktywność fizjologiczną i plon wierzby wiciowej (Salix viminalis L.), Biostymulatory $\mathrm{w}$ nowoczesnej uprawie roślin. Wieś Jutra, 84.

19. Wróbel J., Woźniak A. 2008b. Wpływ sposobów stosowania stymulatora wzrostu Atonik na skład chemiczny wierzby wiciowej Salix viminalis $L$., uprawianej na różnych podłożach. Biostymulatory w nowoczesnej uprawie roślin. Wieś Jutra, 86. 